KINETIK, Vol.1, No.1, Mei 2016, Hal. 33-38

ISSN : 2503-2259,

E-ISSN : 2503-2267

\title{
Interaktif Augmented Reality untuk Katalog Penjualan Rumah Berbasis Android
}

\author{
Lailatul Husniah ${ }^{\star 1}$, Fendy Saputro ${ }^{2}$, Eko Budi Cahyono ${ }^{3}$ \\ 1,2,3Universitas Muhammadiyah Malang \\ husniah@umm.ac.id*
}

\begin{abstract}
Abstrak
Pertumbuhan bisnis properti di Indonesia setiap tahun mengalami peningkatan, namun tidak banyak pihak pengembang properti di Indonesia yang memanfaatkan teknologi Augmented Reality (AR) sebagai media promosi untuk memasarkan produk, rata-rata masih menggunakan brosur. Penelitian tentang katalog penjualan rumah menggunakan AR juga bukan hal baru, ada beberapa penelitian sejenis yang sudah pernah dilakukan sebelumnya, namun dikonsentrasikan pada pendeteksian marker untuk menampilkan model 3D baik menggunakan marker khusus atau brosur yang dijadikan sebagai marker. Marker yang berhasil dideteksi menampilkan objek denah dan bentuk rumah 3D. Penelitian ini fokus pada pembuatan katalog penjualan rumah menggunakan teknologi AR dengan menambahkan fitur yang belum ada pada penelitian sebelumnya. Beberapa fitur yang ditambahkan adalah mengubah warna cat dinding, pintu dan jendela pada model rumah 3D, sehingga pengguna dapat mengubah warna sesuai dengan warna yang disediakan. Katalog penjualan rumah menggunakan teknologi $A R$ yang dikembangkan berjalan pada platform android mobile dan dibuat menggunakan aplikasi Unity. Metode yang digunakan pada penelitian ini adalah SDLC Waterfall. Hasil pengujian menunjukkan bahwa aplikasi dapat berjalan sesuai dengan yang direncanakan khususnya fitur-fitur yang ditambahkan seperti fitur untuk mengganti warna cat dinding, pintu dan jendela pada objek rumah 3D dapat dijalankan dengan baik.
\end{abstract}

Kata kunci: Interactive Augmented Reality, katalog rumah, Android, dan 3D model

\begin{abstract}
In Indonesia, the property business has increased every year, but not many property developers in Indonesia that utilizes Augmented Reality (AR) as a promotion media to market the product. They still rely on brochures as media promotion. Research on sales catalog home using $A R$ is also not new, there are few similar studies that have been done before, but concentrated on the detection marker to display a $3 D$ model using either marker or special brochures that serve as a marker. Markers were detected can displays shapes and sketch of object 3D house. This study focused on the manufacture of home sales catalog using AR technology by adding features that did not exist in previous research. Some of the added features are changing the paint color of walls, doors and windows in a 3D model of a house, so that users can change color according to the shade provided. Home sales catalog using $A R$ technology developed runs on android mobile platform and created using Unity. The method used in this study is the SDLC Waterfall. The test results showed that the application can run as planned, especially the features that are added as a feature to change the paint color of the walls, doors and windows in the house $3 D$ objects can be run properly.
\end{abstract}

Keywords: Interactive Augmented Reality, home sales catalogs, Android, and 3D models

\section{Pendahuluan}

Augmented reality (AR) adalah sebuah istilah untuk lingkungan yang menggabungkan dunia nyata dan dunia virtual yang dibuat oleh komputer sehingga batas antara keduanya menjadi sangat tipis dan lebih dekat kepada lingkungan nyata (real) [1]. Augmented Reality (AR) memungkinkan pengguna untuk berinteraksi dengan objek virtual dan benda-benda nyata 
dalam lingkungan nyata secara real time [2]. Beberapa aplikasi dikembangkan menggunakan teknologi augmented reality seperti aplikasi medis, manufaktur, visualisasi, perencanaan jalur, hiburan, dan militer yang telah dieksplorasi [3].

Pertumbuhan bisnis properti di Indonesia setiap tahun mengalami peningkatan, namun tidak banyak pihak pengembang properti di Indonesia yang memanfaatkan teknologi Augmented Reality (AR) sebagai media promosi untuk memasarkan produk, rata-rata masih menggunakan brosur. Selain menggunakan brosur banyak pengembang properti yang telah membuat aplikasi mengenai pemasaran rumah yang berbasis web atau katalog-katalog yang disediakan dalam web.

Penelitian tentang pembuatan katalog rumah menggunakan AR juga bukan hal baru, ada beberapa penelitian sejenis yang sudah pernah dilakukan sebelumnya, namun dikonsentrasikan pada pendeteksian marker untuk menampilkan model 3D baik menggunakan marker khusus atau brosur yang dijadikan sebagai marker [1][4][5]. Selain konsentrasi pada pendeteksian marker ada beberapa fitur yang ditambahkan seperti menampilkan denah rumah baik 3D maupun 2D dan bentuk rumah 3D berdasarkan studi kasus yang diambil [4][5].

Penelitian ini fokus pada pembuatan katalog penjualan rumah menggunakan teknologi AR dengan menambahkan fitur yang belum ada pada penelitian sebelumnya. Beberapa fitur yang ditambahkan adalah mengubah warna cat dinding, pintu dan jendela pada model rumah $3 \mathrm{D}$, sehingga pengguna dapat mengubah warna sesuai dengan warna yang disediakan.

\section{Metode Penelitian}

Software Development Life Cycle (SDLC) adalah proses yang digunakan oleh industri perangkat lunak untuk merancang, mengembangkan dan menguji software[6]. SDLC bertujuan untuk menghasilkan perangkat lunak yang memenuhi atau melebihi harapan pelanggan, mencapai penyelesaian dalam waktu dan biaya yang sudah direncanakan. Ada beberapa model SDLC yang sudah dibuat seperti model waterfall, spiral, V-Model, rapid prototyping, dan iterative model [6]. Penelitian ini menggunakan metode SDLC model waterfall merupakan suatu proses pengembangan perangkat lunak yang berurutan, di mana setiap tahap harus diselesaikan terlebih dahulu sebelum memasuki tahap berikutnya yang dilihat sebagai aliran air yang terus mengalir ke bawah (seperti air terjun) melewati tahap-tahap yang ada yaitu tahap perencanaan, pemodelan/perancangan, implementasi, dan pengujian [7].

\subsection{Tahap Analisis}

Tahap Analisis sering dikenal sebagai Software Requirements Specification (SRS) merupakan deskripsi lengkap dan komprehensif dari perilaku perangkat lunak yang akan dikembangkan [7]. Proses analisis berguna untuk menjelaskan semua proses yang terjadi dalam aplikasi yang akan dibuat. Analisis proses pada aplikasi interkatif AR untuk katalog penjualan rumah meliputi analisis kebutuhan sistem baik kebutuhan fungsional dan kebutuhan non fungsional, pembuatan flowchart, use case diagram, activity diagram, sequence diagram, serta class diagram. Berkaitan dengan kebutuhan non fungsional aplikasi yang dibangun memiliki spesifikasi dapat beroperasi pada platform smartphone dengan sistem operasi Android minimum 2.3 (gingerbread) dengan RAM minimum 512 MB, dan kamera minimum 3.15 MP. Aplikasi dibangun menggunakan Unity editor dan menggunakan marker. Sedangkan untuk kebutuhan fungsional berkaitan dengan fungsionalitas dari sebuah sistem yang dapat digambarkan melalui use case diagram. Ada beberapa kebutuhan fungsional yang direncanakan yaitu pengguna dapat melakukan download marker yang disediakan, melihat dan memilih menu aplikasi yang disediakan, mengganti warna cat dinding, pintu dan jendela pada model rumah 3D, melihat harga rumah, melihat denah rumah 3D, dan memutar objek rumah 3D.

KINETIK Vol. 1, No. 1, Mei $2016:$ 33-38 


\subsection{Tahap Desain}

Tahap desain merupakan proses perencanaan dan pemecahan masalah untuk solusi perangkat lunak seperti menentukan rencana untuk solusi yang meliputi desain algoritma, arsitektur desain perangkat lunak, skema konseptual database, desain konsep, desain GUI, dan definisi struktur data [7]. Aplikasi interaktif AR untuk katalog penjualan rumah memiliki arsitektur desain perangkat lunak yang di gambarkan pada Gambar 2. Arsitektur sistem tersebut menggambarkan bahwa pengguna aplikasi melakukan capture marker untuk menampilkan model rumah 3D dan mengoperasikan fitur-fitur yang telah disediakan sehingga pengguna dapat mengetahui informasi tentang detail rumah yang ditawarkan. Desain marker dan contoh desain interface ditunjukkan pada Gambar 3.

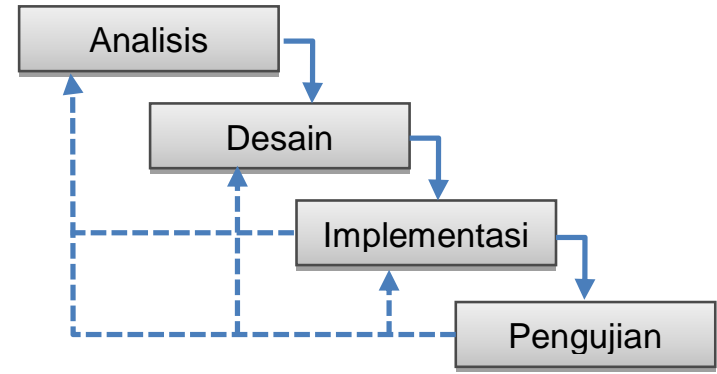

Gambar 1. Metode SDLC: Waterfall model [7]

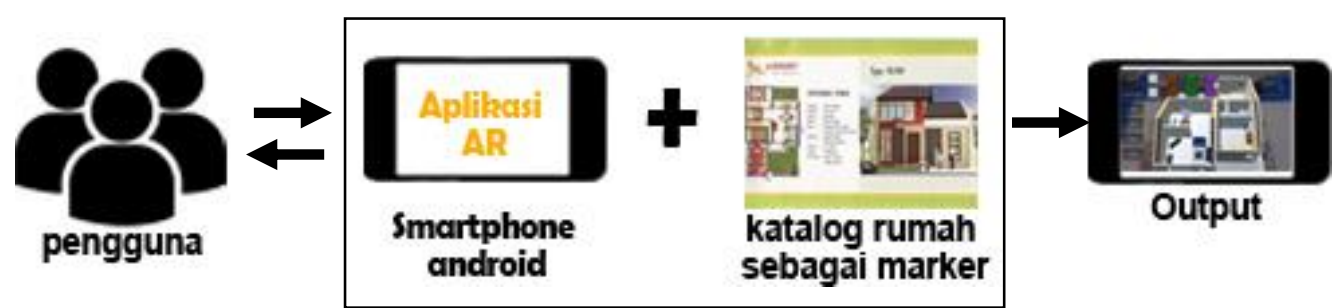

Gambar 2. Arsitektur desain perangkat lunak aplikasi Augmented Reality katalog penjualan rumah
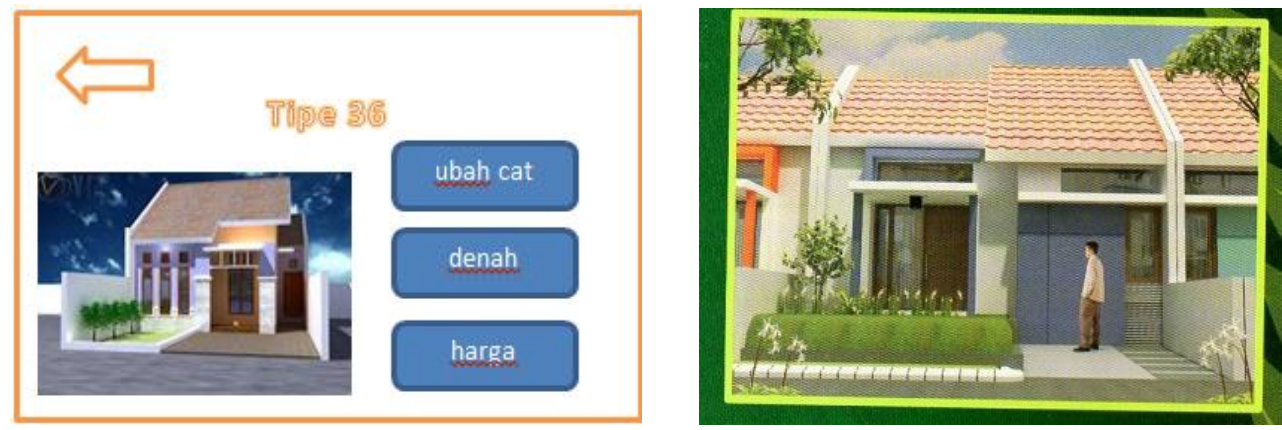

Gambar 3. Contoh desain interface dan desain marker yang dibuat

\subsection{Tahap Implementasi}

Tahap implementasi mengacu pada realisasi bisnis requirements dan spesifikasi desain ke dalam program yang konkret, database, website, atau komponen perangkat lunak melalui pemrograman dan pengembangan dan merupakan tahap dimana kode nyata ditulis dan dikompilasi menjadi aplikasi operasional, dan dimana database serta file teks dibuat. Intinya pada tahap implementasi adalah proses konversi seluruh requirements dan blueprints ke dalam lingkungan produksi [7]. Untuk aplikasi interkatif AR untuk katalog penjualan rumah ada 
beberapa proses yang dilakukan pada tahap imlementasi yang mengacu pada hasil dari tahap analisis dan desain yang meliputi pembuatan marker, pembuatan objek 3D, pembuatan aplikasi interaktir AR untuk katalog penjualan rumah dan pembuatan interface meliputi pembuatan splash screen aplikasi, pembuatan menu utama aplikasi, dan pembuatan menu aplikasi AR.
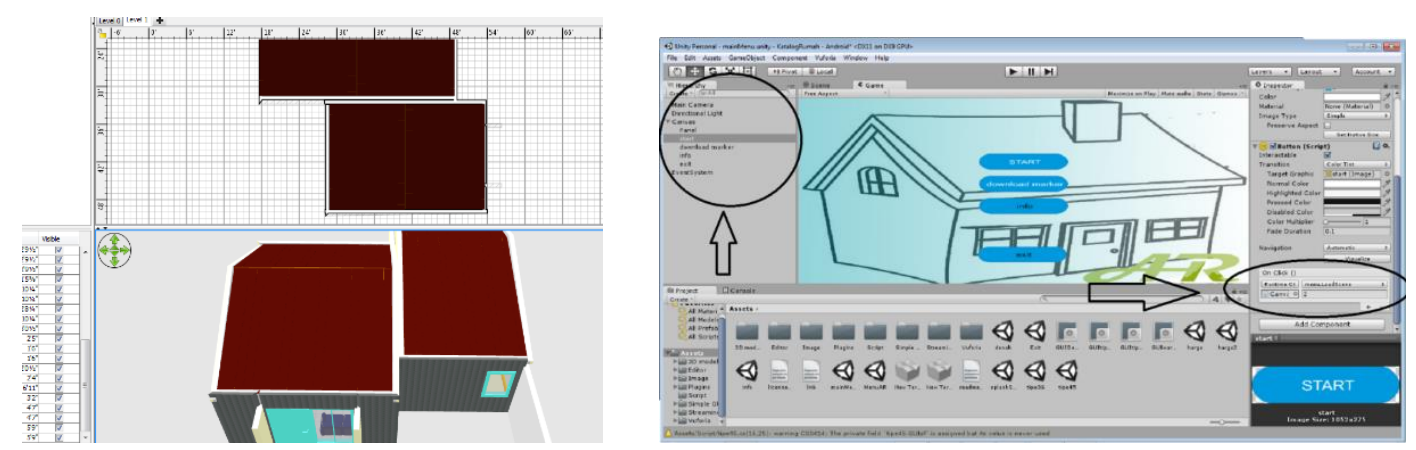

Gambar 4. Contoh pembuatan objek 3D rumah dan pembuatan interface menu utama aplikasi

\subsection{Tahap Pengujian}

Tahap pengujian dikenal sebagai verifikasi dan validasi yang merupakan proses untuk memeriksa bahwa solusi perangkat lunak memenuhi original requirements dan spesifikasi dimana hal tersebut menyelesaikan tujuan yang telah ditetapkan. Verifikasi adalah proses evaluasi perangkat lunak untuk menentukan apakah produk dari suatu tahap pengembangan memenuhi kondisi yang ditentukan pada awal dari tahap terseut, sedangkan validasi adalah proses mengevaluasi software selama atau pada akhir proses pengembangan untuk menentukan apakah memenuhi persyaratan yang ditentukan [7]. Sehingga pengujian yang dilakukan pada aplikasi interkatif AR untuk katalog penjualan rumah menggunakan teknik pengujian black-box untuk mengetahui keberhasilan dari tujuan awal yang ditetapkan.

\section{Hasil Penelitian dan Pembahasan}

Hasil yang dicapai pada penelitian ini adalah aplikasi interaktif AR untuk katalog penjualan rumah menggunakan dua tipe marker yang mewakili masing-masing tipe rumah yaitu marker untuk rumah tipe 45 dan marker untuk rumah tipe 36. Marker yang digunakan berbentuk katalog rumah, dengan melakukan capture marker tersebut menggunakan kamera HP pengguna dapat menggunakan aplikasi ini untuk melihat spesifikasi rumah, model rumah 3D, denah rumah 3D, mengganti warna cat dinding, pintu dan jendela rumah, memutar objek rumah 3D, dan melihat harga rumah tersebut sesuai dengan tipe rumah. Tabel 1 menunjukkan marker yang digunakan pada aplikasi interaktif AR untuk katalog penjualan rumah.

Tabel 1. Marker yang digunakan pada aplikasi interaktif AR untuk penjualan katalog rumah

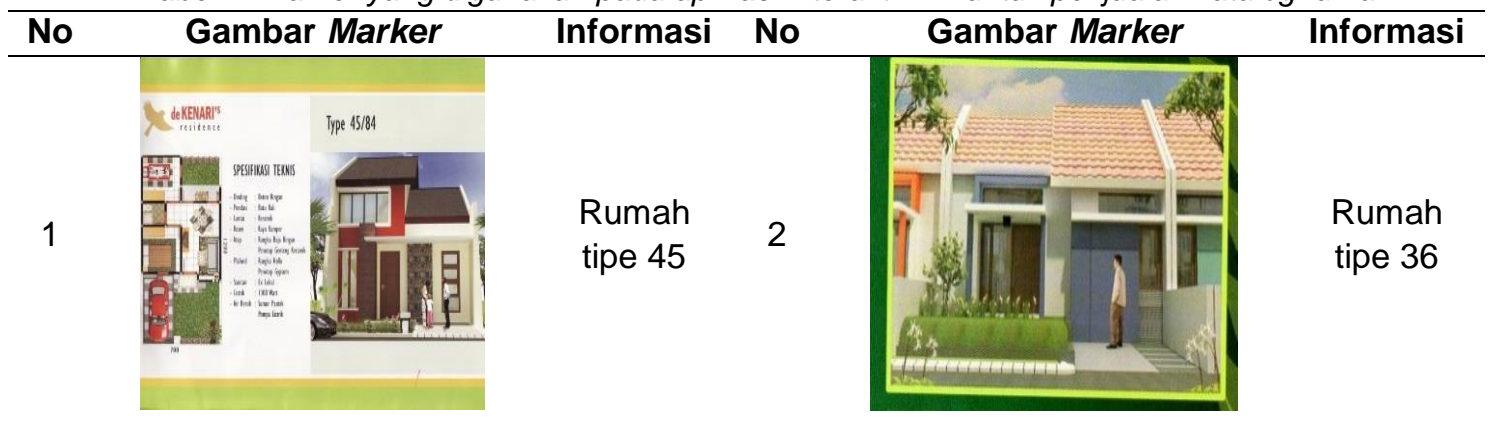

KINETIK Vol. 1, No. 1, Mei 2016: 33-38 


\subsection{Hasil Penelitian}

Hasil penelitian berupa aplikasi interaktif AR untuk katalog penjualan rumah yang dapat dijalankan pada smartphone yang memiliki spesifikasi sistem operasi Android minimum 2.3 (gingerbread) dengan RAM minimum $512 \mathrm{MB}$, dan kamera minimum 3.15 MP. Untuk hasil yang dijabarkan pada Tabel 3, aplikasi dijalankan pada smartphone Samsung core GT-i8262 dengan spesifikasi RAM 1GB, versi Android 4.1.2, memori internal 4GB, dan layar 4.5 inch.

Tabel 2. Hasil pengujian fungsionalitas aplikasi interaktif $A R$ untuk penjualan katalog rumah

\begin{tabular}{|c|c|c|c|c|}
\hline No & Pengujian & Hasil yang diharapkan & Hasil pengujian & kesimpulan \\
\hline 1 & Install APK & $\begin{array}{l}\text { Proses instalasi berjalan sukses } \\
\text { dan aplikasi terpasang pada } \\
\text { smartphone Android dengan baik }\end{array}$ & $\begin{array}{l}\text { Sesuai yang } \\
\text { diharapkan }\end{array}$ & Valid \\
\hline 2 & $\begin{array}{l}\text { Menjalankan aplikasi } \\
\text { yang terpasang }\end{array}$ & $\begin{array}{l}\text { Aplikasi dapat berjalan dengan } \\
\text { baik }\end{array}$ & $\begin{array}{l}\text { Sesuai yang } \\
\text { diharapkan }\end{array}$ & Valid \\
\hline 3 & $\begin{array}{l}\text { Pendeteksian } \\
\text { marker }\end{array}$ & $\begin{array}{l}\text { Marker yang digunakan dapat } \\
\text { dideteksi sehingga objek rumah } \\
\text { 3D dan denah rumah 3D dapat } \\
\text { ditampilkan }\end{array}$ & $\begin{array}{l}\text { Sesuai yang } \\
\text { diharapkan }\end{array}$ & Valid \\
\hline 4 & Tombol START & $\begin{array}{l}\text { Tampil halaman menu aplikasi } \\
\text { AR }\end{array}$ & $\begin{array}{l}\text { Sesuai yang } \\
\text { diharapkan }\end{array}$ & Valid \\
\hline 5 & $\begin{array}{l}\text { Tombol download } \\
\text { marker }\end{array}$ & $\begin{array}{l}\text { Tampil halaman untuk download } \\
\text { marker }\end{array}$ & $\begin{array}{l}\text { Sesuai yang } \\
\text { diharapkan }\end{array}$ & Valid \\
\hline 6 & Tombol Info & $\begin{array}{l}\text { Tampil halaman informasi } \\
\text { seputar aplikasi AR yang dibuat }\end{array}$ & $\begin{array}{l}\text { Sesuai yang } \\
\text { diharapkan }\end{array}$ & Valid \\
\hline 7 & Tombol Ganti Cat & $\begin{array}{l}\text { Warna cat dinding pada objek } \\
\text { rumah } 3 D \text { berubah sesuai warna } \\
\text { yang dipilih }\end{array}$ & $\begin{array}{l}\text { Sesuai yang } \\
\text { diharapkan }\end{array}$ & Valid \\
\hline 8 & $\begin{array}{l}\text { Tombol Cat Pintu } \\
\text { Jendela }\end{array}$ & $\begin{array}{l}\text { Warna cat pintu dan jendela pada } \\
\text { objek rumah } 3 D \text { berubah sesuai } \\
\text { warna yang dipilih }\end{array}$ & $\begin{array}{l}\text { Sesuai yang } \\
\text { diharapkan }\end{array}$ & Valid \\
\hline 9 & Tombol Denah & $\begin{array}{l}\text { Tampil halaman untuk } \\
\text { pendeteksian denah ruang } \\
\text { dengan dua tipe rumah yaitu } \\
\text { denah tipe rumah } 36 \text { dan tipe } \\
\text { rumah } 45\end{array}$ & $\begin{array}{l}\text { Sesuai yang } \\
\text { diharapkan }\end{array}$ & Valid \\
\hline 10 & Tombol Harga & $\begin{array}{l}\text { Tampil halaman yang terdapat } \\
\text { informasi harga rumah }\end{array}$ & $\begin{array}{l}\text { Sesuai yang } \\
\text { diharapkan }\end{array}$ & Valid \\
\hline 11 & Tombol Rotasi & Objek rumah 3D dapat di putar & $\begin{array}{l}\text { Sesuai yang } \\
\text { diharapkan }\end{array}$ & Valid \\
\hline 12 & Tombol Keluar & Keluar dari aplikasi & $\begin{array}{l}\text { Sesuai yang } \\
\text { diharapkan }\end{array}$ & Valid \\
\hline
\end{tabular}

\subsection{Hasil Pengujian}

Pengujian yang dilakukan menggunakan teknik pengujian black-box dengan tujuan untuk mengetahui keberhasilan dari tujuan awal yang ditetapkan dan menguji fungsionalitas dari fiturfitur yang ada pada aplikasi, khususnya fitur untuk mengganti warna cat dinding, pintu dan jendela. Hasil pengujian black-box dapat dilihat pada Tabel 2. 


\section{Kesimpulan}

Kesimpulan yang dapat diambil dari hasil dan pembahasan sebelumnya adalah aplikasi interaktif AR untuk katalog penjualan rumah dapat berjalan sesuai dengan perancangan yang telah dilakukan. Pendeteksian marker pada aplikasi telah berjalan dengan baik sehingga objek rumah 3D maupun denah rumah 3D dapat ditampilkan. Tombol-tombol pada aplikasi ini dapat berjalan sesuai dengan apa yang telah direncanakan. Implementasi interaksi sentuhan tangan pada tombol maupun pada objek dapat berjalan sesuai skenario. Jika Tombol Ganti Cat mengubah warna cat dinding sesuai dengan warna yang dipilih sedangkan tombol rotasi akan membuat objek rumah 3D berputar. Fitur-fitur yang di tambahkan seperti mengganti warna cat dinding, pintu dan jendela dapat berjalan dengan baik.

Tabel 3. Hasil dari aplikasi interaktif AR untuk penjualan katalog rumah

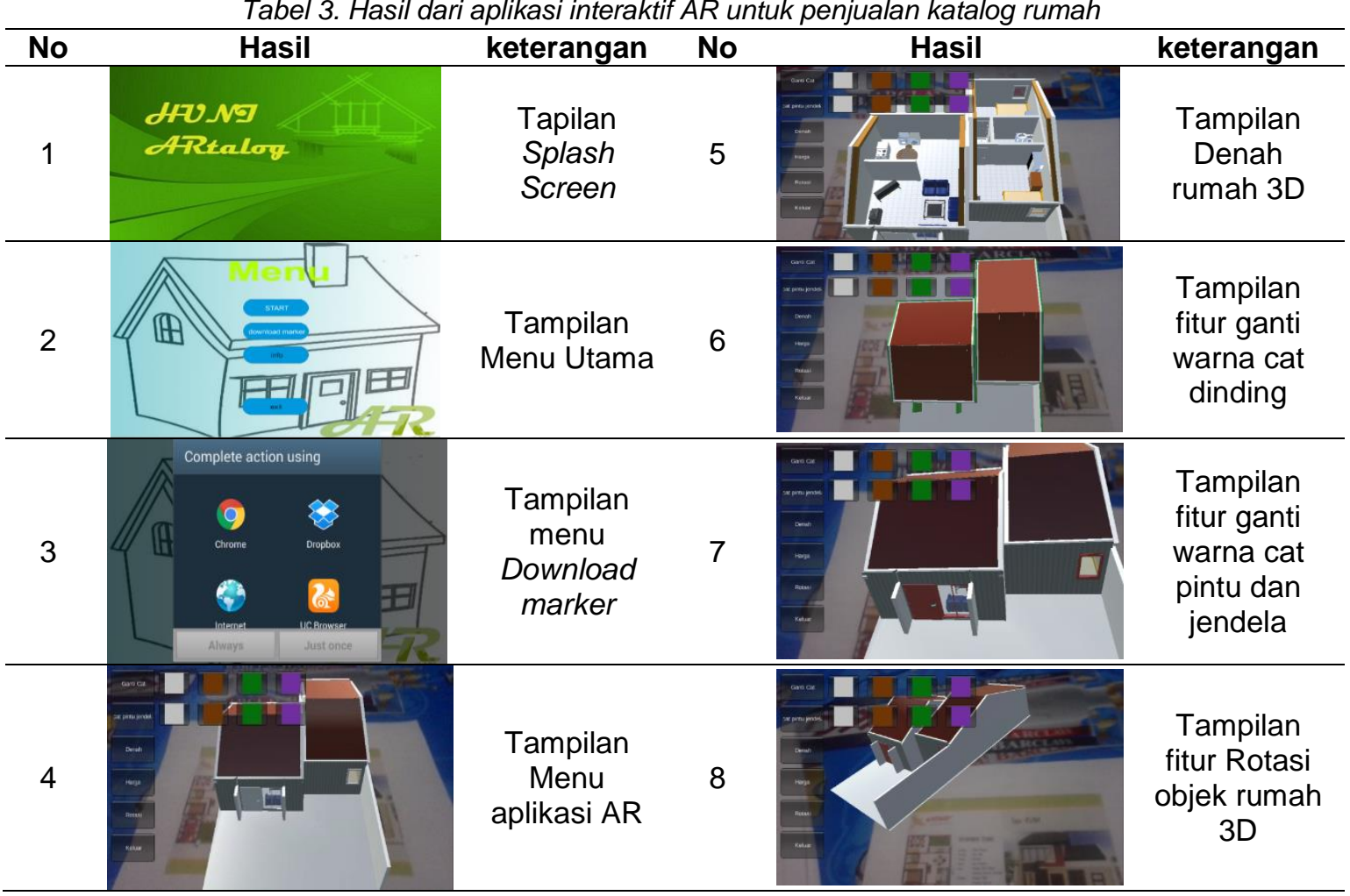

\section{Refrensi}

[1] Gorbala BT, Hariadi M. Aplikasi Augmented Reality untuk Katalog Penjualan Rumah. Institut Sepuluh Nopember Surabaya. 2010.

[2] Matkovic K, Psik T, Wagner I, Gračanin D. Dynamic texturing of real objects in an augmented reality system. InVirtual Reality, 2005. Proceedings. VR 2005. IEEE 2005 Mar 12 (pp. 257-260). IEEE.

[3] Azuma RT. A survey of augmented reality. Presence: Teleoperators and virtual environments. 1997 Aug;6(4):355-85.

[4] Rifa'i M, Listyorini T, Latubessy A. Penerapan Teknologi Augmented Reality pada aplikasi katalog rumah berbasis android. Prosiding SNATIF. 2014 Jan 9:267-74.

[5] Putri P, Afriyantari D. Augmented Reality Untuk Bisnis Properti Sebagai Sarana Pemasaran Berbasis Android (Doctoral dissertation, Universitas Muhammadiyah Surakarta).

[6] Balaji S, Murugaiyan MS. Waterfall vs. V-Model vs. Agile: A comparative study on SDLC. International Journal of Information Technology and Business Management. 2012 Jun 29;2(1):26-30.

[7] Bassil Y. A simulation model for the waterfall software development life cycle. arXiv preprint arXiv:1205.6904. 2012 May 31. 